\title{
PERCUTANEOUS TOXICITY AND DECONTAMINATION OF SOMAN, VX, AND PARAOXON IN RATS USING DETERGENTS
}

\author{
Jan MISÍK ${ }^{1}$, Růžena PAVLIKOVÁ ${ }^{1}$, Jiří CABAL ${ }^{1}$, and Kamil KUČA ${ }^{1,2}$ \\ Faculty of Military Health Sciences, University of Defence ${ }^{1}$, University Hospital ${ }^{2}$, Hradec Kralove, Czech Republic
}

Received in July 2012

CrossChecked in April 2013

Accepted in March 2013

\begin{abstract}
Highly toxic organophosphorus compounds (OPs) were originally developed for warfare or as agricultural pesticides. Today, OPs represent a serious threat to military personnel and civilians. This study investigates the in vivo decontamination of male Wistar rats percutaneously exposed to paraoxon and two potent nerve agents - soman (GD) and VX. Four commercial detergents were tested as decontaminants - Neodekont ${ }^{\mathrm{TM}}$, $\operatorname{Argos}^{\mathrm{TM}}$, Dermogel ${ }^{\mathrm{TM}}$, and FloraFree ${ }^{\mathrm{TM}}$. Decontamination performed $2 \mathrm{~min}$ after exposure resulted in a higher survival rate in comparison with non-decontaminated controls. The decontamination effectiveness was expressed as protective ratio (PR, median lethal dose of agent in decontaminated animals divided by the median lethal dose of agent in untreated animals). The highest decontamination effectiveness was consistently achieved with $\operatorname{Argos}^{\mathrm{TM}}$ ( $\mathrm{PR}=2.3$ to 64.8$)$, followed by Dermogel ${ }^{\mathrm{TM}}$ ( $\mathrm{PR}=2.4$ to 46.1). Neodekont ${ }^{\mathrm{TM}}$ and FloraFree ${ }^{\mathrm{TM}}$ provided the lowest decontamination effectiveness, equivalent to distilled water $(\mathrm{PR}=1.0$ to 43.2$)$.
\end{abstract}

KEY WORDS: Argos $^{T M}$, chemical warfare agent, Dermogel ${ }^{T M}$, FloraFree ${ }^{T M}$, mass decontamination, military toxicology, Neodekont ${ }^{T M}$, protective ratio

Chemical warfare agents (CWAs) are compounds with the potential to be used as weapons of mass destruction. Among them, organophosphorus nerve agents are the most toxic (1). Although they were developed over 70 years ago (before and during World War II), CWAs still pose a threat. Nerve agents, as well as the somewhat less toxic organophosphorus pesticides, could be misused by terrorist groups as cheap and easily obtainable chemical weapons $(1,2)$. Thus, mass decontamination is often discussed in order to establish an optimal decontamination procedure. Compared to military decontamination, mass decontamination requires a different approach, since victims are mainly unskilled to adequately respond and are without the necessary decontamination equipment.
The main approach to preventing the harmful effects of CWAs is to decrease systemic absorption (3). For this purpose, the military uses protective clothes and gas masks, which are not available to civilians during mass casualty scenarios. Therefore, unprotected civilians are under a greater risk of becoming contaminated (mostly through the skin and respiratory system). Thus, an effective decontamination method to counteract the impact of pollutants needs to be made part of the onsite first aid procedure. Many different decontamination methods have been developed (4-6). The most common one for mass casualties is wet type decontamination using detergents $(7,8)$.

In this study, four commercial detergents (Neodekont $^{\mathrm{TM}}$, Argos $^{\mathrm{TM}}{ }^{\mathrm{T}}$ Dermogel $^{\mathrm{TM}}$ and FloraFree ${ }^{\mathrm{TM}}$ ) 
were tested and compared for their decontamination effectiveness in rats pre-exposed to topical nerve agents soman and VX, as well as to an active metabolite of the OP pesticide parathion - paraoxon (Figure 1). The protective ratios (PR) of detergents were determined against the PR of distilled water using a standard in vivo decontamination test $(6,9)$.

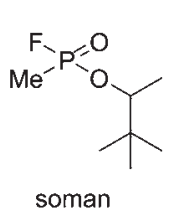

soman

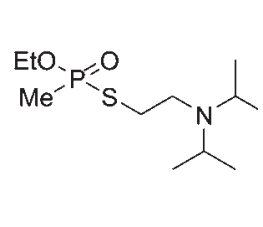

$\mathrm{VX}$

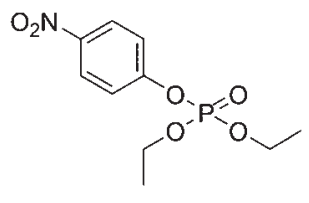

paraoxon
Figure 1 The chemical structure of soman, VX, and paraoxon.

\section{MATERIALS AND METHODS}

\section{Decontaminants and other chemicals}

The nerve agents soman (O-pinakolyl methylphosphonofluoridate) and VX $\{O$-ethyl $S$-[2(diisopropylamino)ethyl] methylphosphonothioate were obtained from Zemianske Kostolany military laboratory (Slovak Republic) and had a purity of $97 \%$ and $90 \%$, respectively. Paraoxon(diethyl 4-nitrophenyl phosphate, $97 \%$ ) was purchased from Sigma Aldrich, Ltd. (Czech Republic). The application of VX required small doses due to its high toxicity; hence dilution was done before administration to animals (2). Accordingly, VX was administrated as a $0.01 \%$ hexane (Sigma Aldrich, Ltd.) solution. The detergents FloraFree ${ }^{\mathrm{TM}}$ (Deb Ltd., United Kingdom), Dermogel ${ }^{\mathrm{TM}}$ (KAO Corporation España, Spain), and Argos ${ }^{\mathrm{TM}}$ (Argos Hygiene Ltd., France) were obtained from the Health Protection Agency (United Kingdom). Neodekont ${ }^{\mathrm{TM}}$ was produced by the ChemProtect corp. (Czech Republic). Argos ${ }^{\mathrm{TM}}$ consists mainly of surfactants (e.g., sodium alkylethersulphate, sodium alkylbenzensulphonate, cocamide diethanol amine, etc.) and other compounds (methylchloroisothiazolinone), while the remaining three detergents contain other compounds such as potassium tallate, isopropyl alcohol, sodium citrate, triclosan, sodium laureth sulphate, triethanolamine lauryl sulphate, glycerin, alkylamide betaine triethanolamine-dodecylbenzene sulphonate, bentonite, etc. All of the detergents were pre-mixed with distilled water $(5.0 \%)$.

\section{Animals}

A total of 327 adult male Wistar rats (b.w. from $180 \mathrm{~g}$ to $210 \mathrm{~g}$ ) were obtained from the Velaz corp. (Czech Republic) and placed at an approved animal facility at the Faculty of Military Health Sciences (FMH). The animals were housed in standard boxes in groups of six and received standard food and drinking water ad libitum. The handling and treatment of the experimental animals were done under the supervision of the Ethics Committee of the FMH and in full accordance with laws and regulations.

\section{Methods}

The acute percutaneous toxicity of the selected OPs was established using a conventional acute toxicity test (10) prior to skin decontamination. Undiluted toxic agents (soman, paraoxon) or hexane diluted VX were topically administered onto clipped dorsal skin $(5 \mathrm{~cm} \times 7 \mathrm{~cm})$ using a pipette. Clipping was performed on the day before the experiment to avoid post-clipping irritation. The animals were placed in a fume hood and restrained on plastic platters during agent application/decontamination. Each experimental group consisted of four to six animals. Four to five different doses of the agent were applied. Decontamination was initiated 2 min after exposure by swabbing the dose site manually by 10 strokes in a head-to-tail direction using a cotton swab $(2.5 \mathrm{~cm} \times 2.5 \mathrm{~cm})$ moistened in a $5 \%$ aqueous solution of a single detergent type and finally dried by another swab. The temperature of the decontamination fluid was maintained at $25^{\circ} \mathrm{C}$. The control group was decontaminated with distilled water instead of a detergent solution following the same protocol. Blank controls $(n=5)$ werefixed, clipped, and "decontaminated" with distilled water without pre-exposure to toxic agents. The animals that survived for $24 \mathrm{~h}$ were euthanized by $\mathrm{CO}_{2}$.

\section{Data analysis}

Acute toxicity was evaluated by assessing the median lethal dose $\left(\mathrm{LD}_{50}, \mathrm{mg} \mathrm{kg}^{-1}\right)$ and its $95 \%$ confidence limits, calculated by a probit analysis of deaths occurring within $2 \mathrm{~h}$ (soman) and $24 \mathrm{~h}$ (VX, paraoxon). The effectiveness of decontamination was expressed as the protective ratio (PR); i.e., the ratio between $\mathrm{LD}_{50}$ in decontaminated animals and $\mathrm{LD}_{50}$ in untreated animals (9). The statistical significance of the difference between decontaminated and nondecontaminated $\mathrm{LD}_{50}$ was assessed on the basis of 
non-overlapping confidence limits. Other results are shown as a mean \pm standard deviation (SD).

\section{RESULTS}

The rats percutaneously poisoned by OPs showed dose-dependent signs of intoxication. In soman poisoned groups, the local fasciculation of dorsal muscles started usually several (from $3 \mathrm{~min}$ to $7 \mathrm{~min}$ ) after application and expanded gradually. The animals that received supra-lethal doses of soman (from $10 \mathrm{mg} \mathrm{kg}^{-1}$ to $40 \mathrm{mg} \mathrm{kg}^{-1}$ ) suffered from strong central convulsions terminated by respiratory crisis (apnoea) and death. When $30 \mathrm{mg} \mathrm{kg}^{-1}$ was administered, convulsions occurred within $(5.3 \pm 1.9) \mathrm{min}$. Mastication, salivation, and piloerection were also observed. Dermal $\mathrm{LD}_{50}$ of soman assessed $2 \mathrm{~h}$ after exposure was $9.83 \mathrm{mg} \mathrm{kg}^{-1}$ (from $5.87 \mathrm{mg} \mathrm{kg}^{-1}$ to $13.63 \mathrm{mg} \mathrm{kg}^{-1}$ ), and it remained the same after $24 \mathrm{~h}$. Compared to soman, VX-poisoned animals showed signs of a cholinergic crisis later on. Local and central convulsions started $(91.8 \pm 6.1)$ min after VX administration at a dose of $0.1 \mathrm{mg} \mathrm{kg}^{-1}$. Hypersalivation, lacrimation, and pilo-erection also occurred as signs of intoxication. Dermal $\mathrm{LD}_{50}$ of diluted VX observed $24 \mathrm{~h}$ after exposure was $0.085 \mathrm{mg} \mathrm{kg}^{-1}$ (from $0.027 \mathrm{mg} \mathrm{kg}^{-1}$ to $0.102 \mathrm{mg} \mathrm{kg}^{-1}$ ). In paraoxon-treated animals, the first signs of intoxication were apparent approx. $4 \mathrm{~h}$ after application (local fasciculation) with
$24 \mathrm{~h} \mathrm{LD}_{50}$ of $4.37 \mathrm{mg} \mathrm{kg}^{-1}$ (from $1.59 \mathrm{mg} \mathrm{kg}^{-1}$ to $\left.8.84 \mathrm{mg} \mathrm{kg}^{-1}\right)$. There were no cholinergic signs or deaths within $2 \mathrm{~h}$ and $24 \mathrm{~h}$ in blank controls.

Animals subjected to decontamination suffered less from cholinergic symptoms compared to nontreated. In all cases, the survival of decontaminated animals increased and deaths were usually related to higher agent doses. In general, the most promising decontamination effectiveness was achieved with Argos ${ }^{\mathrm{TM}}$, followed by Dermogel ${ }^{\mathrm{TM}}$. Lower decontamination effectiveness was found with FloraFree $^{\mathrm{TM}}$ and Neodekont ${ }^{\mathrm{TM}}$ solutions (Table 1, 2, and 3).

\section{DISCUSSION}

\section{Acute toxicity of OPS}

The toxic effect of OPs is caused mainly by the irreversible inhibition of the enzyme acetylcholineseterase (AChE, EC 3.1.1.7), which leads to the accumulation of the neurotransmitter acetylcholine in the central and peripheral nervous systems and ultimately to a fatal impact on neuromuscular transmission $(2,11,12)$. Thus, typical signs of cholinergic crisis were observed in percutaneously intoxicated rats (fasciculation, salivation, etc.). In this study, VX was the most toxic

Table 1 Decontamination effectiveness of detergents against soman

\begin{tabular}{|c|c|c|c|c|c|c|c|c|c|c|c|c|}
\hline \multirow{3}{*}{$\begin{array}{l}\text { Decontamination } \\
\text { effectiveness }\end{array}$} & \multicolumn{10}{|c|}{ Decontaminant $v$ s. soman } & \multicolumn{2}{|c|}{ Acute toxicity of soman } \\
\hline & \multicolumn{2}{|c|}{ Ar } & \multicolumn{2}{|c|}{ De } & \multicolumn{2}{|c|}{ Fl } & \multicolumn{2}{|c|}{$\mathrm{Ne}$} & \multicolumn{2}{|c|}{ water } & \multirow{2}{*}{ D } & \multirow{2}{*}{ M } \\
\hline & D & M & D & M & D & M & D & M & D & M & & \\
\hline & 20 & $1 / 4$ & 20 & $1 / 4$ & 20 & $1 / 4$ & 20 & $1 / 4$ & 20 & $0 / 4$ & 5.0 & $0 / 6$ \\
\hline & 40 & $2 / 4$ & 40 & $3 / 4$ & 40 & $3 / 4$ & 30 & $3 / 4$ & 30 & $3 / 4$ & 10.0 & $3 / 6$ \\
\hline & 60 & $3 / 4$ & 60 & $3 / 4$ & 60 & $3 / 4$ & 40 & $3 / 4$ & 40 & $4 / 4$ & 15.0 & $5 / 6$ \\
\hline & \multirow{2}{*}{80} & \multirow{2}{*}{$4 / 4$} & \multirow{2}{*}{80} & \multirow{2}{*}{$4 / 4$} & \multirow{2}{*}{80} & \multirow{2}{*}{$4 / 4$} & \multirow{2}{*}{60} & \multirow{2}{*}{$4 / 4$} & \multirow{2}{*}{60} & \multirow{2}{*}{$4 / 4$} & 20.0 & $6 / 6$ \\
\hline & & & & & & & & & & & 30.0 & $6 / 6$ \\
\hline $\mathrm{LD}_{50} / \mathrm{mg} \mathrm{kg}^{-1}$ & \multicolumn{2}{|c|}{35.85} & \multicolumn{2}{|c|}{30.70} & \multicolumn{2}{|c|}{30.70} & \multicolumn{2}{|c|}{25.83} & \multicolumn{2}{|c|}{26.72} & 9.83 & \\
\hline LCL / \% & \multicolumn{2}{|c|}{-} & \multicolumn{2}{|c|}{-} & \multicolumn{2}{|c|}{-} & \multicolumn{2}{|c|}{-} & \multicolumn{2}{|c|}{5.98} & 5.87 & \\
\hline UCL / \% & \multicolumn{2}{|c|}{ 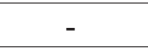 } & \multicolumn{2}{|c|}{ 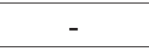 } & \multicolumn{2}{|c|}{-} & \multicolumn{2}{|c|}{-} & \multicolumn{2}{|c|}{38.50} & 13.63 & \\
\hline PR & \multicolumn{2}{|c|}{3.6} & \multicolumn{2}{|c|}{3.1} & & & & & & & & \\
\hline
\end{tabular}

The effectiveness is shown as protective ratio (PR; median lethal dose in decontaminated animals divided by median lethal dose in untreated animals). Mortality $(M)$ is shown as the number of deaths versus the number of animals in the experimental group.

$D$ - dose in $\mathrm{mg} \mathrm{kg}^{-1}$

Ar-Argos ${ }^{T M} ;$ De - Dermogel ${ }^{T M} ; \mathrm{Fl}-$ FloraFree $^{T M} ; \mathrm{Ne}-$ Neodekont $^{T M}$;

$L C L$ - lower confidence limit; UCL - upper confidence limit

Significant difference $(p<0.05)$ between decontaminated $L D_{50}$ and non-treated $L D_{50}$ is marked with an asterisk. 
Table 2 Decontamination effectiveness of detergents against VX

\begin{tabular}{|c|c|c|c|c|c|c|c|c|c|c|c|c|}
\hline \multirow{3}{*}{$\begin{array}{l}\text { Decontamination } \\
\text { effectiveness }\end{array}$} & \multicolumn{10}{|c|}{ Decontaminant vs. VX } & \multicolumn{2}{|c|}{ Acute toxicity of VX } \\
\hline & \multicolumn{2}{|c|}{ Ar } & \multicolumn{2}{|c|}{ De } & \multicolumn{2}{|c|}{ Fl } & \multicolumn{2}{|c|}{$\mathrm{Ne}$} & \multicolumn{2}{|c|}{ water } & \multirow{2}{*}{ D } & \multirow{2}{*}{$\mathbf{M}$} \\
\hline & D & M & D & M & D & M & D & $\mathbf{M}$ & D & M & & \\
\hline & 2.0 & $0 / 4$ & 2.0 & $0 / 4$ & 0.5 & $0 / 4$ & 2.0 & $0 / 4$ & 1.0 & $0 / 4$ & 0.079 & $2 / 6$ \\
\hline & 3.0 & $1 / 4$ & 3.0 & $2 / 4$ & 1.0 & $3 / 4$ & 3.0 & $1 / 4$ & 2.0 & $1 / 4$ & 0.1 & $5 / 6$ \\
\hline & 5.0 & $0 / 4$ & 5.0 & $2 / 4$ & 2.0 & $4 / 4$ & 5.0 & $4 / 4$ & 5.0 & $3 / 4$ & 0.126 & $6 / 6$ \\
\hline & 8.0 & $3 / 4$ & \multirow{2}{*}{8.0} & \multirow{2}{*}{$4 / 4$} & \multirow{2}{*}{3.0} & \multirow{2}{*}{$4 / 4$} & \multirow{2}{*}{8.0} & \multirow{2}{*}{$4 / 4$} & 10.0 & $3 / 4$ & \multirow{2}{*}{0.159} & \multirow{2}{*}{$6 / 6$} \\
\hline & 10.0 & $4 / 4$ & & & & & & & 15.0 & $4 / 4$ & & \\
\hline $\mathrm{LD}_{50} / \mathrm{mg} \mathrm{kg}^{-1}$ & \multicolumn{2}{|c|}{5.51} & \multicolumn{2}{|c|}{3.92} & \multicolumn{2}{|c|}{0.846} & \multicolumn{2}{|c|}{3.45} & \multicolumn{2}{|c|}{3.67} & \multicolumn{2}{|l|}{0.085} \\
\hline LCL / \% & \multicolumn{2}{|c|}{3.00} & \multicolumn{2}{|c|}{-} & \multicolumn{2}{|c|}{0.003} & \multicolumn{2}{|c|}{2.10} & \multicolumn{2}{|c|}{0.82} & \multicolumn{2}{|l|}{0.027} \\
\hline UCL / \% & \multicolumn{2}{|c|}{17.95} & \multicolumn{2}{|c|}{-} & \multicolumn{2}{|c|}{1.889} & \multicolumn{2}{|c|}{33.32} & \multicolumn{2}{|c|}{9.52} & 0.102 & \\
\hline PR & \multicolumn{2}{|c|}{$64.8^{*}$} & \multicolumn{2}{|c|}{46.1} & & & & & & & & \\
\hline
\end{tabular}

See Table 1 for a more detailed explanation.

Table 3 Decontamination effectiveness of detergents against paraoxon

\begin{tabular}{|c|c|c|c|c|c|c|c|c|c|c|c|c|}
\hline \multirow{3}{*}{$\begin{array}{l}\text { Decontamination } \\
\text { effectiveness }\end{array}$} & \multicolumn{10}{|c|}{ Decontaminant vs. paraoxon } & \multicolumn{2}{|c|}{ Acute toxicity of paraoxon } \\
\hline & \multicolumn{2}{|c|}{ Ar } & \multicolumn{2}{|c|}{ De } & \multicolumn{2}{|c|}{ Fl } & \multicolumn{2}{|c|}{$\mathrm{Ne}$} & \multicolumn{2}{|c|}{ water } & \multirow{2}{*}{ D } & \multirow{2}{*}{ M } \\
\hline & D & M & D & M & D & M & D & M & D & M & & \\
\hline & 5.0 & $0 / 4$ & 5.0 & $0 / 4$ & 2.5 & $0 / 4$ & 2.5 & $0 / 4$ & 2.0 & $0 / 4$ & 2.0 & $0 / 5$ \\
\hline & 10.0 & $2 / 4$ & 10.0 & $1 / 4$ & 5.0 & $1 / 4$ & 5.0 & $0 / 4$ & 4.0 & $2 / 4$ & 5.0 & $3 / 5$ \\
\hline & 15.0 & $2 / 4$ & 15.0 & $4 / 4$ & 10.0 & $4 / 4$ & 10.0 & $4 / 4$ & 8.0 & $3 / 4$ & 10.0 & $5 / 5$ \\
\hline & 20.0 & $4 / 4$ & 20.0 & $4 / 4$ & 15.0 & $4 / 4$ & 15.0 & $4 / 4$ & 12.0 & $4 / 4$ & 20.0 & $5 / 5$ \\
\hline $\mathrm{LD}_{50} / \mathrm{mg} \mathrm{kg}^{-1}$ & \multicolumn{2}{|c|}{11.34} & \multicolumn{2}{|c|}{10.62} & \multicolumn{2}{|c|}{9.91} & \multicolumn{2}{|c|}{7.07} & \multicolumn{2}{|c|}{4.52} & 4.37 & \\
\hline LCL / \% & \multicolumn{2}{|c|}{-} & \multicolumn{2}{|c|}{-} & \multicolumn{2}{|c|}{2.65} & \multicolumn{2}{|c|}{-} & \multicolumn{2}{|c|}{0.52} & 1.59 & \\
\hline UCL / \% & \multicolumn{2}{|c|}{-} & \multicolumn{2}{|c|}{-} & \multicolumn{2}{|c|}{18.16} & \multicolumn{2}{|c|}{-} & \multicolumn{2}{|c|}{10.52} & 8.84 & \\
\hline PR & \multicolumn{2}{|c|}{2.6} & \multicolumn{2}{|c|}{2.4} & \multicolumn{2}{|c|}{2.3} & \multicolumn{2}{|c|}{1.6} & \multicolumn{2}{|c|}{1.0} & & \\
\hline
\end{tabular}

See Table 1 for a more detailed explanation.

agent with $\mathrm{LD}_{50}$ being less than $0.1 \mathrm{mg} \mathrm{kg}^{-1}$, which is in concordance with established data on VX (2), even though it was diluted. In some studies, dilution was found to elevate skin permeation in vitro $(13,14)$, which could possibly lead to an earlier manifestation of cholinergic signs and higher VX toxicity in vivo. On the other hand, Hamilton et al. (15) found little or no effect of dilution on VX absorption. The extreme toxicity of agent VX is caused by a preferential reaction with $\mathrm{AChE}$, contrary to G-agents which are more willing to be hydrolyzed by other $\mathrm{ChE}$ (2). Although VX was the most toxic, cholinergic signs occurred relatively late $(1.5 \mathrm{~h})$ compared to soman. When high doses of soman were applied, a rapid manifestation of $\mathrm{AChE}$ inhibition occurred in several minutes (fasciculation, central convulsions). In supralethal doses, other cholinergic signs such as hypersalivation or mastication usually did not firmly manifest because of an early onset of central symptoms followed by rapid death. Muscarinic signs were observed mainly in sub-lethal (mainly miosis, hypersalivation, and piloerection) and lethal doses (all of the mentioned signs). The rapidity of soman's effect can be explained by its high lipophilicity, which supports easy passage through the blood-brain barrier (16). Animals surviving $2 \mathrm{~h}$ also survived a $24 \mathrm{~h}$ exposure in all cases. In paraoxon, mild cholinergic symptoms (fasciculation) started $1.5 \mathrm{~h}$ under a high dose $\left(20 \mathrm{mg} \mathrm{kg}^{-1}\right)$ and several hours after lower doses (from $2 \mathrm{mg} \mathrm{kg}^{-1}$ to $5 \mathrm{mg} \mathrm{kg}^{-1}$ ). Finally, even when the onset of signs was mild, the $\mathrm{LD}_{50}$ of paraoxon was approximately $50 \%$ lower than the $\mathrm{LD}_{50}$ of nerve agent soman after $24 \mathrm{~h}$ of exposure.

\section{Decontamination of $O P$}

Wet type decontamination using detergents reduced the symptoms of OP toxicity. Deaths were either fewer or associated with higher doses of OPs. 
All of the detergents provided a low or modest level of protection, which was attributed to their low detoxification potency $(17,18)$ and the low solubility of lipophilic OPs in water solutions $(2,17)$. The lowest decontamination effectiveness was achieved against paraoxon ( $\mathrm{PR}=1.6$ to 2.6 ), followed by soman ( $\mathrm{PR}=2.6$ to 3.6). A more effective decontamination was achieved against VX (PR=10.0 to 64.8) which penetrated tissue slowly (15) and was not significantly absorbed during 2 min of exposure. Moreover, a low dose of VX was easily removed by a moistened cotton swab during decontamination. Argos ${ }^{\mathrm{TM}}$ and Dermogel ${ }^{\mathrm{TM}}$ were more effective in OP decontamination, whereas Neodekont ${ }^{\mathrm{TM}}$ and FloraFree ${ }^{\mathrm{TM}}$ provided lower decontamination effectiveness corresponding to that of distilled water or even lower. As for VX decontamination, both Neodekont ${ }^{\mathrm{TM}}$ and FloraFree ${ }^{\mathrm{TM}}$ were less effective than distilled water, suggesting the enhancement of skin permeation after washing with detergent solutions, as demonstrated in vitro $(14,19$, $20)$. Although the chemical composition of the tested detergents was similar, the highest decontamination effectiveness against all of the tested OPs was consistently achieved with Argos ${ }^{\mathrm{TM}}$, which was also the most effective in the decontamination of sulphur mustard (9). The slight difference in the chemical composition of detergents apparently went in favour of $\operatorname{Argos}^{\mathrm{TM}}$, which is a relatively simple mixture of two primary and one secondary surfactant with a minor additive content to reduce the detergency effect of the surfactants (9).

Several more effective reactive and non-reactive decontamination methods or special preventatives as barrier creams were evaluated as countermeasures against CWAs (e.g., 6, 18, 21, 22). Most of them require skilled or prophylactic application and are appropriate only in the military domain. On the other hand, non-reactive detergents and soapy water are useful in mass decontamination facilities because of their availability, low health risk, and low skill requirements. Despite the fact that none of the studied detergents were able to effectively eliminate OPs from the skin, their use in emergencies could delay a fatal impact on victims. They could provide precious time for transport and subsequent medication of victims by pharmaceuticals such as anticholinergics (atropine) and $\mathrm{AChE}$ reactivators $(23,24)$.

Mass casualty decontamination requires a certain amount of time for technical implementation, which usually delays treatment. The response time is an important factor which influences the effectiveness of the decontamination $(15,17,25,26)$. In this study, decontamination was performed 2 min after exposure and the effectiveness would have certainly been decreased had the treatment been delayed. Another in vivo study (27) showed a good effectiveness for detergents used in the delayed decontamination of VX; however, as demonstrated, VX is a relatively slowacting agent. Thus, further investigation is needed to evaluate the effectiveness of delayed decontamination against more rapid G-agents.

\section{CONCLUSIONS}

The harmful effect of OPs could be counteracted prior to systemic absorption using an appropriate decontamination method. In this study, wet type decontamination using four commercial detergents originally developed for cleaning and decontamination purposes were tested against OPs. All of the detergents generally provided modest protection against soman and paraoxon ( $\mathrm{PR}=1.6$ to 3.6). Higher protection was achieved against $\mathrm{VX}(\mathrm{PR}=10.0$ to 64.8$)$. According to the obtained results, $\operatorname{Argos}^{\mathrm{TM}}(\mathrm{PR}=2.3$ to 64.8$)$ should be investigated as a possible decontaminant in mass casualty scenarios. Moreover, the search for more effective alternatives should be considered.

\section{Acknowledgements}

This work was supported by the European Union Executive Agency for Health and Consumers (ORCHIDS project) with contributions from the longterm organization development plan 1011.

\section{Conflict of Interest Declaration}

The authors report no conflicts of interest. The authors alone are responsible for the content of the paper.

\section{REFERENCES}

1. Greenfield RA, Brown BR, Hutchins JB, Iandolo JJ, Jackson R, Slater LN, Bronze MS. Microbiological, biological, and chemical weapons of warfare and terrorism. Am J Med Sci 2002;323:326-40

2. Munro NB, Ambrose KR, Watson AP. Toxicity of the organophosphate chemical warfare agents GA, GB and VX: implications for public protection. Environ Health Perspect 1994;102:18-38.

3. Gupta RC, editor. Handbook of Toxicology of Chemical Warfare Agents. $1^{\text {st }}$ ed. London: Elsevier Inc; 2009. 
4. Yang YC, Baker JA, Ward JR. Decontamination of chemical warfare agents. Chem Rev 1992;92:1729-43. doi: 10.1021/cr00016a003

5. Tiwari S, Ghosh KK, Marek J, Kuca K. Functionalized surfactant mediated reactions of carboxylate, phosphate and sulphonate esters. J Phys Org Chem 2010;23:519-25. doi: $10.1002 /$ poc. 1635

6. Cabal J, Kassa J, Severa J. A comparison of the decontamination efficacy of foam-making blends based on cationic and nonionic tensides against organophosphorus compounds determined in vitro and in vivo. Hum Exp Toxicol 2003;22:507-14. doi: 10.1191/0960327103ht377oa

7. Amlôt R, Larner J, Matar H, Jones DR, Carter H, Turner EA, Price SC, Chilcott RP. Comparative analysis of showering protocols for mass-casualty decontamination. Prehos Disaster Med 2010;25:435-39. doi: 10.1017/S1049023X00008529

8. Zilker T. Medical management of incidents with chemical warfare agents. Toxicology 2005;214:221-31. doi: 10.1016/ j.tox.2005.06.028

9. Misik J, Pavlikova R, Cabal J, Vodakova E, Kuca K. A comparison of decontamination effects of commercially available detergents in rats preexposed to topical sulphur mustard. Cutan Ocul Toxicol 2013;32:135-9. doi: 10.3109/ 15569527.2012.730087

10. Lipnick RL, Cotruvo JA, Hill RN, Bruce RD, Stitzel KA, Walker AP, Chus I, Goddards M, Segal L, Springer JA, Myers RC. Comparison of the up-and-down, conventional LD50, and fixed-dose acute toxicity procedures. Food Chem Toxicol 1995;33:223-31.

11. Maxwell DM, Brecht KM, Koplovitz I, Sweeney RE. Acetylcholinesterase inhibition: does it explain the toxicity of organophosphorus compounds? Arch Toxicol 2006;80:75660. doi: $10.1007 / \mathrm{s} 00204-006-01$

12. Bajgar J. Organophosphates/nerve agent poisoning: mechanism of action, diagnosis, prophylaxis, and treatment Adv Clin Chem 2004;38:151-216.

13. Dalton $\mathrm{CH}$, Hattersley IJ, Rutter SJ, Chilcott RP. Absorption of the nerve agent VX (O-ethyl-S-[2(diisopropylamino)ethyl] methyl phosphonothioate) through pig, human and guinea pig skin in vitro. Toxicol In Vitro 2006;20:1532-6. doi: 10.1016/j.tiv.2006.06.009

14. Moody RP, Maibach HI. Skin decontamination: Importance of the wash-in effect. Food Chem Toxicol 2006;44:1783-8. doi: 10.1016/j.fct.2006.05.020

15. Hamilton MG, Hill I, Conley J, Sawyer TW, Caneva DC, Lundy PM. Clinical aspects of percutaneous poisoning by the chemical warfare agent VX. Effects of application site and decontamination. Mil Med 2004;169:856-62.

16. Joosen MJ, van den Boom JE, Kuijpers TM, Smit WC, Lucassen AB, van Helden HP. Long-term cognitive deficits accompanied by reduced neurogenesis after soman poisoning. Neurotoxicology 2009;30:72-80. doi: 10.1016/j. neuro.2008.11.010
17. Bjarnason S, Mikler J, Hill I, Tenn C, Garrett M, Caddy N, Sawyer TW. Comparison of selected skin decontaminant products and regimens against VX in domestic swine. Hum Exp Toxicol 2008;27:253-61. doi: 10.1177/ 0960327108090269

18. Braue EH Jr, Smith KH, Doxzon BF, Lumpkin HL, Clarkson ED. Efficacy studies of reactive skin decontamination lotion, M291 skin decontamination kit, $0.5 \%$ bleach, $1 \%$ soapy water, and skin exposure reduction paste against chemical warfare agents, Part 2: Guinea pigs challenged with soman. Cutan Ocul Toxicol 2011;30:29-37. doi: 10.3109/15569527 .2010.515281

19. Loke WK, Lau SK, Lim JS, Tay GS, Koh CH. Wet decontamination-induced stratum corneum hydration: effects on the barrier function to diethylmalonate. J Appl Toxicol 1999;19:285-90. doi: 10.1002/(SICI)10991263(199907/08)19:4<275::AID-JAT578>3.0.CO;2-B

20. Misik J, Pavlikova R, Josse D, Cabal J, Kuca K. In vitro skin permeation and decontamination of the organophosphorus pesticide paraoxon under various physical conditions evidence for a wash-in effect. Toxicol Mech Methods 2012;22:520-5. doi: 10.3109/15376516.2012.686535

21. Chilcott RP, Dalton CH, Hill I, Davison CM, Blohm KL, Clarkson ED, Hamilton MG. Evaluation of a barrier cream against the chemical warfare agent VX using the domestic white pig. Basic Clin Pharmacol Toxicol 2005;97:35-8.

22. Taysse L, Daulon S, Delamanche S, Bellier B, Breton P. Skin decontamination of mustards and oranophosphates: comparative efficiency of RSDL and Fuller's earth in domestic swine. Hum Exp Toxicol 2007;26:135-41. doi: 10.1177/0960327107071866

23. Kuca K, Jun D, Musilek K. Structural requirements of acetylcholinesterase reactivators. Mini Rev Med Chem 2006;6:269-77.

24. Kuca K, Jun D, Bajgar J. Currently used cholinesterase reactivators against nerve agent intoxication: comparison of their effectivity in vitro. Drug Chem Toxicol 2007;30:3140.

25. Knezevic D, Tadic V, Katic S. Combined decontamination and parenteral therapy improve the chances of survival in rats percutaneously poisoned with organophosphorus insecticides. Acta Veterinaria (Beograd) 2001;51:187-95.

26. Dorandeu F, Taysse L, Boudry I, Foquin A, Hérodin F, Mathieu J, Daulon S, Cruz C, Lallement G. Cutaneous challenge with chemical warfare agents in the SKH-1 hairless mouse. (I) Development of a model for screening studies in skin decontamination and protection. Hum Exp Toxicol 2011;30:470-90. doi: 10.1177/0960327110373615

27. Misik J, Pavlik M, Novotny L, Pavlikova R, Chilcott RP, Cabal J, Kuca K. In vivo decontamination of the nerve agent VX using the domestic swine model. Clin Toxicol 2012;50:807-11. doi: 10.3109/15563650.2012.720986 


\section{Sažetak}

\section{PERKUTANA TOKSIČNOST I DEKONTAMINACIJA SOMANA, VX-A I PARAOKSONA U ŠTAKORA DETERDŽENTIMA}

Visokotoksični organofosforni spojevi (krat. OP) prvotno su se proizvodili za ratovanje i uporabi u poljoprivredi kao pesticidi. Danas su nepobitno iznimna prijetnja vojnom osoblju i civilima. Ova studija istražuje in vivo dekontaminaciju muških štakora Wistar perkutano izloženih paraoksonu i dvama snažnim nervnim agensima - somanu (GD) i VX-u. Četiri komercijalna deterdženta ispitana su kao sredstva dekontaminacije - Neodekont, Argos, Dermogel i FloraFree. Dekontaminacija dvije minute nakon izlaganja rezultirala je višom stopom preživljavanja u usporedbi s nedekontaminiranom kontrolnom skupinom. Učinkovitost dekontaminacije izražena je kao zaštitni omjer (PR, medijan smrtonosne doze agenta u dekontaminiranih životinja podijeljen s medijanom smrtonosne doze agenta u nedekontaminiranih životinja). Najveća konzistentna učinkovitost postignuta je Argosom ( $\mathrm{PR}=2.3$ do 64.8) i Dermogelom (PR=2.4 do 46.1). Deterdženti Neodekont i FloraFree bili su najmanje učinkoviti i imali jednak učinak kao destilirana voda $(\mathrm{PR}=1.0$ do 43.2).

KLJUČNE RIJEČI: Argos, Dermogel, FloraFree kemijski ratni agens, masovna dekontaminacija, Neodekont, vojna toksikologija, zaštitni odnos

\section{CORRESPONDING AUTHOR:}

Jan Misik

Faculty of Military Health Sciences

University of Defence

Trebesska 1575

50001 Hradec Kralove, Czech Republic

E-mail:misik@pmfhk.cz 